\title{
OPEM
}

www.opem.org

Oriental Pharmacy and Experimental Medicine 2008 8(4), 339-348

DOI 10.3742/OPEM.2008.8.4.339

\section{Anti-Salmonella activity of a flavonone from Butea frondosa bark in mice}

\author{
Uma Shankar Mishra ${ }^{1 \dagger}$, Noton Kumar Dutta ${ }^{1,2 \dagger}$, Kaushiki Mazumdar,3, Santosh Kumar \\ Mahapatra $^{1}$, Pronobesh Chakraborty ${ }^{4}$ and Sujata G Dastidar ${ }^{1, *}$ \\ ${ }^{I}$ Division of Microbiology, Department of Pharmaceutical Technology, Jadavpur University, Calcutta 700032, \\ India; ${ }^{2}$ Department of Laboratory Animal Medicine, College of Veterinary Medicine, Seoul National University, \\ San 56-1, Sillim-Dong, Gwanak-Gu, Seoul 151-742, Republic of Korea; ${ }^{3}$ Department of Microbiology and \\ Immunology, College of Medicine, Seoul National University, 28 Yongon-Dong, Jongno-Gu, Seoul 110-799, \\ Republic of Korea; ${ }^{4}$ Gupta College of Technological Sciences, Asansol, West Bengal, India
}

Received for publication July 30, 2007; accepted January 21, 2008

\begin{abstract}
SUMMARY
Butea frondosa has been used traditionally as a topical formulation in the treatment of many diseases and disorders. Two compounds [BF-1 (crystalline flavonol quercetin) and BF-2 (tannin) from ethyl acetate fraction of ethanolic extract] were isolated from the bark of Butea frondosa. The stereostructures of the compounds were determined on the basis of chemical and physicochemical evidence. BF-1 and BF-2 were screened in vitro for possible antibacterial property against 112 bacteria comprising 3 genera of Gram-positive and 12 genera of Gram-negative types. It was found that both BF-1 and BF-2 exhibited inhibitory activity against several bacteria. Most of these strains were inhibited by BF-1 at $50-200 \mu \mathrm{g} / \mathrm{ml}$, while BF-2 (MIC ${ }_{50} 400 \mu \mathrm{g} / \mathrm{ml}$ ) was much less active. The bacteria could be arranged in the decreasing order of sensitivity towards BF-1 in the following manner: S. aureus, Bacillus spp., Salmonella spp., Vibrio spp., Shigella spp., E. coli and Pseudomonas spp. The $\mathrm{MIC}_{50}$ of the compound was $50 \mu \mathrm{g} / \mathrm{ml}$ while the $\mathrm{MIC}_{90}$ was $100 \mu \mathrm{g} / \mathrm{ml}$. The decreasing order of sensitivity towards BF-2 was V. cholerae, Bacillus spp., S. aureus, V. parahaemolyticus, Salmonella spp. and Proteus spp. BF-1 was bactericidal in action. In vivo studies with this extract showed that it could offer statistically significant protection $(p<0.01)$ to mice challenged with a virulent bacterium. The inhibitory activity of Butea frondosa against Gram-positive and Gram-negative bacteria indicates its usefulness in the treatment of common bacterial infections. The potentiality of BF1 as an antibacterial agent may be confirmed further by pharmacological studies.
\end{abstract}

Keywords: Butea frondosa; ethyl acetate fraction; quercetin; antimicrobial activity; in vitro; in vivo

\section{INTRODUCTION}

Chemotherapeutics and antibiotics have offered effective therapies for the prevention and treatment

*Correspondence: Sujata G Dastidar, Division of Microbiology, Department of Pharmaceutical Technology, Jadavpur University, Calcutta 700 032, India. E-mail: noton_kaushiki@yahoo.co.in

The first two authors contributed equally to this work of many diseases caused by several species of microorganisms for the past several decades. These achievements, however, have also posed the inevitable threat of acquired bacterial drug resistance. Over the last few years, both the frequency and spectrum of multi-resistant species of pathogenic bacteria have noticeably increased (Cohen, 1992; Neu, 1992). Even today, there are species of Streptococcus, Staphylococcus, Pseudomonas, Enterococcus and Mycobacterium that 
have developed resistance to all existing antibiotic therapies (Davies, 1994, 1996; Nikaido, 1994; Spratt, 1994). Unfortunately, few new antimicrobial drugs are reported to be under active development (Travis, 1994). Under such intimidating circumstances, there is an urgent need to be pursued to meet the upcoming challenges that are being caused by the emergence of multidrug resistance in bacteria.

The use of plant-based therapeutics by man is as old as the history of man himself. Even today, many scholars are of the view that traditional medical systems based on plant products continue to lead in many human groups. It is useless to mention that nearly three-fourth of modern medicines have plant constituents in them in some form. In Ayurveda, about 2000 plant species have been considered to possess medicinal value. Ayurveda, or the science of life, is the holistic alternative science from Asia and is believed to be the oldest healing science in existence, forming the foundation of all others. Asia has a rich resource of medicinal plants that are widely used in the traditional system of medicines since inception of human culture.

The plant kingdom, holding many species of plants, is constantly being screened for its pharmacological properties and new plant drugs are continuing to find their way into the medical world.

There are other important reasons to undertake research on medicinal plants. They include documentation and conservation of the deteriorating traditional medical system, as most of these practices are transmitted by word of mouth. Provision of scientific background in support of folk curative practices and identification of a cheap drug of plant origin with least side effect and maximum therapeutic potential are essential. Finally, efforts should be made to elucidate the mechanism of action of plant-based drugs in animal models.

Butea frondosa Koenigex Roxb. (Palas), a member of the family Fabaceae/Leguminosae, may be one such example of the indigenous system of medicines. The plant encompasses a wide range of therapeutic activities, some of which have been discovered and put into practice successfully. The various parts used in traditional medicine are gum, seeds, flowers, bark and leaves of the plant. The leaves and flowers of B. frondosa are used as astringent, tonic, aphrodisiac, depurative, diuretic and poultice. The seeds of the plant are used as laxative and anthelmintic. The gums of $B$. frondos $a$ are traditionally used for their astringent, antidiarrhoeal, antidysenteric and anthelmintic properties (Kaleysa et al., 1962) and also in the treatment of septic sore throat and phthisis (Kirtikar and Basu, 1975; Nadkarni, 1976; Lal et al., 1976). Butea frondosa is reported to be associated with hepatoprotective (Rane and Grampurohit, 1998), antiestrogenic properties (Kapila et al., 1970; Razdan et al., 1970; Shah et al., 1990; Anonymous, 1998; Bhatwadekar et al., 1999). Unfortunately, this particular plant has not been extensively explored. The present study has been undertaken to investigate the antimicrobial activity of the stem bark of this immensely useful plant. The bark of the tree was obtained and dried following standard extraction procedures and tested for antibacterial activity. A detailed chemical characterization was accompanied with an extensive in vitro and in vivo analysis.

Butea frondosa bark contains many constituents. In this study, we report for the first time the presence of quercetin (flavonone) as one of the constituents. There are reports on the antimicrobial activity of quercetin. However, this study aims to investigate its broad-spectrum efficacy and its ability to protect the mouse from an infection caused by a highly virulent strain of Salmonella typhimurium. S. typhimurium causes mild gastroenteritis in humans but is lethal in mice. Thus, infection of mice with $S$. typhimurium provides a murine model for typhoid fever as it bears many similarities to human serovar typhi infection. We have already established the characteristics of gastritis caused by Salmonella typhimurium (intraperitoneal $\mathrm{LD}_{50}-0.95 \times$ $10^{9}$ ) in mice and determined the changes of histopathological lesions and bacterial colonization 
in mice stomachs with a time course of infection (Dastidar et al., 2001, 2004).

\section{MATERIALS AND METHODS}

\section{Plant material}

The bark of Butea frondosa (Family Fabaceae/ Leguminosae) was collected from forest region (Balasore) of Orissa, India. The plant part was authenticated by Central National Herbarium, Botanical Survey of India, Botanical Gardens, Howrah, India. This tree, growing up to $12-15 \mathrm{~m}$, is irregularly branched, with a rough grey bark. Leaves are large with petioles $10-15 \mathrm{~cm}$ long, stipules linear-lanceolate, deciduous, leaflets coriaceous, all obtuse, glabrous above when old, silky and prominently reticulately veined below. Flowers are large, bright orange, in rigid racemes $15 \mathrm{~cm}$ long, 3 flowers arising together. Calyx is $13 \mathrm{~mm}$ long, dark green; corolla $3-3.5 \mathrm{~cm}$ long (Tandon and Shivanna, 2003).

\section{Compounds}

The bark of Butea frondosa was ground by electric grinder and screened through $1.4 \mathrm{~mm}$ mesh sieve. The extraction in $98 \%$ ethanol was carried out with the extract to solvent ratio $1: 10$ for a period of $20 \mathrm{~h}$ with intermittent stirring. The extract was evaporated under vacuum at $50^{\circ} \mathrm{C}$ to approximately one-tenth of its original volume, purified by liquid-liquid extraction method with n-hexane, ethyl acetate and distilled water and stored at $4{ }^{\circ} \mathrm{C}$. The color of dried $\mathrm{n}$-hexane and ethyl acetate fractions were yellowish and reddish sticky, respectively.

The physical characteristics (color, nature, solubility, Rf values and melting point or decomposition temperature) of the isolated compounds and their chemical reactions with different reagents were determined with the help of standard methods (Trease and Evans, 1985; Wallis, 1985; Plummer, 1985). The isolation and purification of the compounds were performed by TLC [ $5 \times 20 \mathrm{~cm}$ size glass plate, $20 \%$ suspension of silica gel G (E-Merck), $0.25 \mathrm{~mm}$ layer thickness of spreader, activated at $1100{ }^{\circ} \mathrm{C}$ for $30 \mathrm{~min}$, solvent system chloroform : methanol (1 : $1)$, visualizing agent iodine vapor and UV light (366 nm)].

Column chromatography was done [absorbent, silica gel for column (60 - 120 mesh), grade (E-Merck), mobile phase; chloroform: methanol $(1: 1)$, quantity of each fraction collected - $20 \mathrm{ml}$; glass column size $-60 \times 30 \mathrm{~mm}$, number of column elutes from columns 1 to 23 (ethyl acetate fraction) and 1 to 8 (n-hexane fraction)]. It was further subjected to chemical tests and confirmation of Rf values, UV-visible spectra [Systronics double beam spectrophotometer2101, Absorption maxima ( $\left.\lambda_{\max } \mathrm{nm}\right) 257$ to 356], IR spectrum and H-NMR spectrum. Elemental analysis and mixed melting point determination were also performed (Markham, 1982; Breitmaier, 1993). All compounds were stored at $4{ }^{\circ} \mathrm{C}$.

\section{Quercetin (BF-1) and Tannin (BF-2)}

Ethyl acetate fraction $10-12$ yielded a deep yellow sticky mass, which was washed successively with excess amount of petroleum ether to remove the sticky matter and re-crystallized with the help of dilute alcohol to obtain a light yellow crystalline powder. This product was named as BF-1. Ethyl acetate fraction 16 - 19 yielded a reddish brown sticky mass, which was successively washed in petroleum ether to remove the sticky matter and re-crystallized with acetone (irregular fragments). This product was named as BF-2. Melting point of BF-1 was $309{ }^{\circ} \mathrm{C}$ to $311{ }^{\circ} \mathrm{C}$, yield was $0.07 \%$, Rf value was found to be 0.97 (chloroform : methanol $=1: 1$ ). Elemental analysis calculated for $\mathrm{C}_{15} \mathrm{H}_{10} \mathrm{O}_{7}$ was $\mathrm{C} 59.51 ; \mathrm{H} 3.30$, found were $\mathrm{C} 59.60 ; \mathrm{H} 3.32$. Melting point of $\mathrm{BF}-2$ was $118^{\circ} \mathrm{C}$ to $120^{\circ} \mathrm{C}$ (decomposed). Yield was $0.29 \%$ and $\mathrm{Rf}$ value was 0.72 (chloroform : methanol = $1: 1)$. The UV-visible spectra, H-NMR and IR spectra of the isolated compounds were determined (data not presented). From all the furnished experimental evidences on mixed melting point determination with the authentic sample of quercetin, it was concluded that the new isolated crystalline 
<smiles>O=c1c(O)c(-c2ccc(O)c(O)c2)oc2cc(O)cc(O)c12</smiles>

Fig. 1. Structure of BF-1.

compound BF-1 is a flavonoid compound quercetin. BF-2 is found to be tannin. The structure of BF-1 has been described in Fig. 1 .

\section{Bacteria}

A total of 112 strains of bacteria belonging to 15 different genera comprising 3 Gram-positive and 12 Gram-negative types were tested. These were clinical isolates of human origin, identified as described by Barrow and Feltham (1993) and preserved in freeze-dried state.

\section{Media for antibacterial screening studies}

Liquid media used were peptone water [PW, bacteriological peptone (Oxoid) 1\% (w/v) plus $\mathrm{NaCl}$ (Analar) $0.5 \%(\mathrm{w} / \mathrm{v})]$ and nutrient broth (NB, Oxoid). Solid media were Mueller-Hinton agar (MHA, Oxoid), nutrient agar (NA, Oxoid) and desoxycholate citrate agar (DCA, Oxoid). MHA was supplemented with $5 \%$ defibrinated sheep blood where necessary. The $\mathrm{pH}$ was maintained at 7.2 - 7.4 for all the media. NA was used for tests with Gram-positive bacteria and DCA was used for the rest of the bacteria, particularly Proteus spp. Salmonella strains were grown in Brain Heart infusion (BHI, Difco).

\section{Determination of Minimum Inhibitory Concen-} tration (MIC) of the compounds BF-1 and BF-2

The MIC of the compounds with respect to different test bacteria was accurately determined by agar dilution method. For this, the compounds were dissolved in dimethyl sulfoxide (DMSO), and added at concentrations of 0 (control), 10, 25, 50, 100 and $200 \mu \mathrm{g} / \mathrm{ml}$ in molten NA/DCA/MHA and poured in For Salmonella strains, broth dilution method was employed. Final inocula of $5 \times 10$ Petridishes, according to NCCLS guidelines (NCCLS, 1993; Koneman et al., 1997). The organisms were grown in respective liquid media, and the overnight cultures were spot-inoculated on the Petridishes, such that each inoculum contained $2 \times 10^{5} \mathrm{CFU}$ (colony forming units). The plates were incubated at $37^{\circ} \mathrm{C}$, examined after $24 \mathrm{~h}$ and incubated further for $72 \mathrm{~h}$, where necessary. The lowest concentration of the compound in a plate that failed to show any visible macroscopic growth was considered as its MIC. The MIC determination was performed in triplicate for each organism, and the experiment was repeated where necessary. For Salmonella strains, broth dilution method was employed. Final inocula of $5 \times 10^{5}$ to $1 \times 10^{6} \mathrm{CFU} / \mathrm{ml}$ were prepared by diluting overnight cultures in fresh broth. MIC was determined by spectrophotometric method after $24 \mathrm{~h}$ of incubation at $37^{\circ} \mathrm{C}$ (Washington and Sutter, 1980). The antimicrobial efficacy of BF1 was compared with that of ampicillin.

\section{Determination of the mode of action of BF-1 on} Salmonella typhimurium NCTC 74

Salmonella typhimurium NCTC 74 was grown in BHI overnight at $37^{\circ} \mathrm{C}$. From this culture, $2 \mathrm{ml}$ was added to $4 \mathrm{ml}$ of fresh BHI and incubated for $2 \mathrm{~h}$ so that the culture could attain the logarithmic growth phase. The number of viable cells (CFU) was then determined and BF-1 was added at a concentration higher than its MIC value $(50 \mu \mathrm{g} / \mathrm{ml})$ with respect to the test bacterium. The CFU counts were determined up to $6 \mathrm{~h}$ at intervals of $2 \mathrm{~h}$ and then after 18 h. (Krogstad and Moellering, 1990).

\section{In vivo tests}

In vivo experiments were performed following our institutional guidelines for the care and use of laboratory animals.

Swiss strain of male white mice, each weighing 
$20 \mathrm{~g}$, was used for the in vivo studies. Animals were maintained at standard conditions at $21 \pm 1{ }^{\circ} \mathrm{C}$ and $50-60 \%$ relative humidity, with a photoperiod of $14: 10 \mathrm{~h}$ of light-darkness. Water and a dry pellet diet were given ad libitum. The virulence of the test strain Salmonella typhimurium NCTC 74 was exalted by repeated mouse passage and the median lethal dose (MLD or $L D_{50}$ ) of the passaged strain (corresponding to $0.95 \times 10^{9} \mathrm{CFU} /$ mouse suspended in $\left.0.5 \mathrm{ml} \mathrm{BHI}\right)$ served as the challenge dose for all animals (Reed and Muench, 1938). Reproducibility of the challenge dose was ensured by standardization of its optical density in a Klett-Summerson colorimeter at $640 \mathrm{~nm}$.

To determine the toxicity of BF-1, 40 mice were taken, 20 of which were injected $60 \mu \mathrm{g}$ of the compound and the rest 20 received $30 \mu \mathrm{g}$ of BF-1. They were kept under observation up to $100 \mathrm{~h}$. Subsequently, two separate groups of mice, 20 animals per group, were kept in different cages. Each animal in Group I was intraperitoneally administered $30 \mu \mathrm{g}$ BF-1 $(0.1 \mathrm{ml}$ from $300 \mu \mathrm{g} / \mathrm{ml}$ solution of BF-1) and Group II was given $60 \mu \mathrm{g}$ of BF-1 per mouse $(0.1 \mathrm{ml}$ from $600 \mu \mathrm{g} / \mathrm{ml}$ solution of BF-1). After $3 \mathrm{~h}$, each group was challenged with 50 MLD of S. typhimurium NCTC 74. A control group of 40 mice was also injected similarly with the same bacterial strain, and $0.1 \mathrm{ml}$ sterile saline instead of BF-1. The protective capacity of BF-1 was determined by recording the mortality of the mice in different groups up to $100 \mathrm{~h}$ of the treatment, and statistically by $\chi^{2}$ test.

In another experiment, 4 groups of mice, 5 animals per group, were taken. Groups 1 and 3 were administered $60 \mu \mathrm{g}$ of BF-1, while groups 2 and 4 were given $0.1 \mathrm{ml}$ sterile saline. After $3 \mathrm{~h}$, all the groups were given a 50 MLD challenge of $S$. typhimurium NCTC 74. After $2 \mathrm{~h}$, groups 1 and 2 were sacrificed. Their heart blood was collected aseptically; their livers and spleens were removed and homogenized in tissue homogenizers. CFU counts of the individual organs were determined separately. The same procedure was applied on groups 3 and $4,18 \mathrm{~h}$ after the challenge. Statistical analysis of the in vivo data was done by Student's $t$-test.

\section{Histopathological examination}

Liver and spleen samples were fixed in $10 \%$ neutral formalin for $24 \mathrm{~h}$. Formalin-fixed tissues were dehydrated in an alcohol-xylene series and embedded in paraffin wax. From each block, sections $2 \mu \mathrm{m}$ thick were prepared and stained with haematoxylin and eosin (HE) for histopathological examination. Changes in the experimental histopathologic parameters for liver and spleen tissues were graded as follows: (-) showing no changes, and $(+),(++)$ and $(+++)$ indicating minimum, moderate and maximum changes, respectively. These values were considered to be non-parametric, and therefore the data was statistically analyzed in order to determine the effects of all groups on each of the experimental parameters, and compare the means of each parameter between the groups. A $p$-value of $<0.05$ was considered significant.

\section{RESULTS}

\section{Bacterial inhibitory spectra of BF-1 and BF-2}

The isolated components of $B$. frondosa were active against both Gram-positive and Gram-negative bacteria. BF-1 was found to be inhibitory against all the bacteria screened, at different concentrations. Out of 112 bacteria, the MIC of BF-1 was $10-50 \mu \mathrm{g} /$ $\mathrm{ml}$ for 86. Strains of Bacillus spp., Staphylococcus aureus, Salmonella spp., Klebsiella spp. and Vibrio spp. were inhibited by BF-1 within $100 \mu \mathrm{g} / \mathrm{ml}$, while those of Proteus spp., Pseudomonas spp. and Enterobacter cloaca within $200 \mu \mathrm{g} / \mathrm{ml}$ (Fig. 2). The $\mathrm{MIC}_{50}$ of the compound was $50 \mu \mathrm{g} / \mathrm{ml}$, while the $\mathrm{MIC}_{90}$ was $100 \mu \mathrm{g} / \mathrm{ml}$ (Table 1).

BF-2 was active at higher concentrations (MIC range from $200-1000 \mu \mathrm{g} / \mathrm{ml}, \mathrm{MIC}_{50}$ was $400 \mu \mathrm{g} / \mathrm{ml}$ ).

Ampicillin was used against 8 strains of Salmonella. The $\mathrm{MIC}_{50}$ and $\mathrm{MIC}_{90}$ were 8 and -16 $\mu \mathrm{g} / \mathrm{ml}$ respectively. 


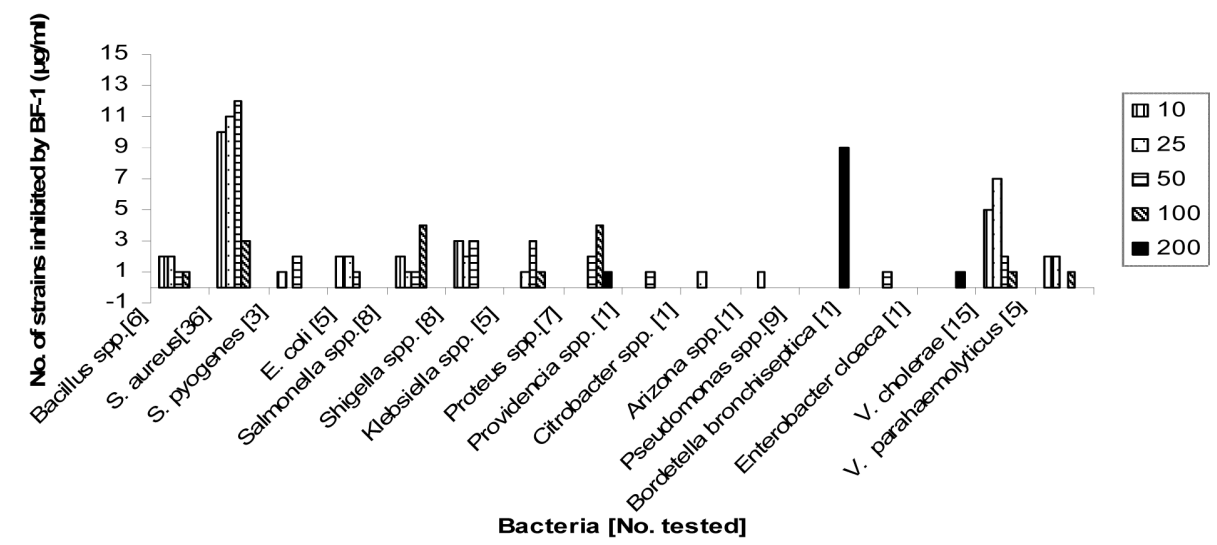

Fig. 2. Antibacterial spectrum of BF-1 in a dose dependent manner.

Table 1. In vitro activity of BF-1 tested against a varity of Gram positive and Gram negative bacteria

\begin{tabular}{lccc}
\hline \multirow{2}{*}{ Bacteria [No of tested] } & \multicolumn{3}{c}{$\mathrm{MIC}(\mu \mathrm{g} / \mathrm{ml})$} \\
\cline { 2 - 4 } & Range & $\mathrm{MIC}_{50}$ & $\mathrm{MIC}_{90}$ \\
\hline Bacillus spp.[6] & $10-100$ & 25 & 100 \\
Staphylococcus aureus[36] & $10-100$ & 25 & 50 \\
Streptococcus pyogenes [3] & $10-100$ & 50 & 50 \\
Escherichia coli [5] & $10-100$ & 25 & 50 \\
Salmonella spp.[8] & $10-100$ & 50 & 100 \\
Shigella spp. [8] & $10-100$ & 25 & 50 \\
Klebsiella spp. [5] & $10-100$ & 50 & 100 \\
Proteus spp.[7] & $50-200$ & 100 & 200 \\
Providencia spp. [1] & 50 & & \\
Citrobacter spp. [1] & 25 & & \\
Arizona spp.[1] & 25 & & \\
Pseudomonas spp.[9] & & 200 & 200 \\
Bordetella bronchiseptica [1] & 50 & & \\
Enterobacter cloaca [1] & 200 & & \\
Vibrio cholerae [15] & $10-100$ & 25 & 100 \\
Vibrio parahaemolyticus [5] & $10-100$ & 25 & 100 \\
\hline Total [112] & $10-200$ & 25 & 100 \\
\hline
\end{tabular}

\section{Kinetic studies on the action of BF-1}

The MIC of BF-1 against Salmonella typhimurium NCTC 74 was found to be $25 \mu \mathrm{g} / \mathrm{ml}$. At the logarithmic growth phase of the culture, when the CFU count of the strain was $1.3 \times 10^{8}, 50 \mu \mathrm{g} / \mathrm{ml}(2 \times$ MIC) of BF-1 was added. Subsequently, the CFU counts of the culture were determined; they were $1.3 \times 10^{5}$ after $2 \mathrm{~h}, 1 \times 10^{4}$ after $4 \mathrm{~h}$ and 0 after $6 \mathrm{~h}$, as well as at the end of $18 \mathrm{~h}$ (Fig. 3).

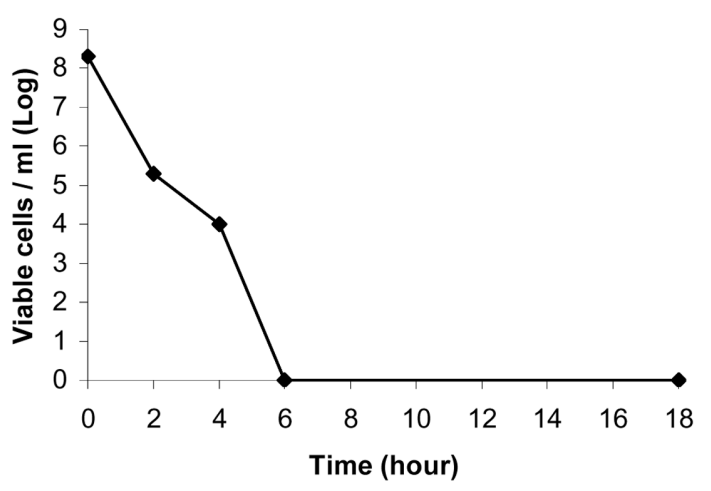

Fig. 3. Mode of action of BF-1 against Salmonella typhimurium NCTC 74.

\section{Protective capacity of BF-1 in vivo}

None of the animals in the two groups of mice (20 in each) receiving $30 \mu \mathrm{g}$ or $60 \mu \mathrm{g}$ of BF-1 died, proving thereby that the compound was non-toxic for the animals. Subsequently, two more groups of mice (20 per group) that were given $30 \mu \mathrm{g}$ or $60 \mu \mathrm{g}$ of BF-1 were challenged with 50 MLD (Table 2) of S. typhimurium NCTC 74 after $3 \mathrm{~h}$. In the first group ( $30 \mu \mathrm{g} /$ mouse), 8 out of 20 animals died, while in the other group $(60 \mu \mathrm{g} /$ mouse), none of the animals died. In the control group of 40 mice challenged with the same strain, 32 animals died within $100 \mathrm{~h}$. On the basis of the data obtained, statistical analysis showed $p<0.01$, according to chi-square test (Table 3). In Fig. 4, it is seen that BF-1 significantly reduced the number of viable bacteria in heart blood, liver and spleen of mice 18 
Table 2. Median lethal dose of Salmonella typhimurium NCTC 74

\begin{tabular}{|c|c|c|c|c|c|c|c|}
\hline \multirow{2}{*}{ Batch } & \multirow{2}{*}{ CFU } & \multirow{2}{*}{$\mathrm{OD}^{*}$} & \multirow{2}{*}{$\begin{array}{l}\text { Mortality data } \\
\text { D/S }\end{array}$} & \multicolumn{2}{|c|}{ Accumulated values from mortality data } & \multirow{2}{*}{ MLD } & \multirow{2}{*}{50 MLD } \\
\hline & & & & Mortality ratio $^{* *} \mathrm{D} / \mathrm{D}+\mathrm{S}$ & $\%$ & & \\
\hline 1 & $2.2 \times 10^{8}$ & 111 & $6 / 6$ & $10 / 10$ & 100 & \multirow{5}{*}{$\begin{array}{c}1.9 \times 10^{7} \\
\mathrm{CFU}\end{array}$} & \multirow{5}{*}{$\begin{array}{c}50 \times 1.9 \times 10^{7} \\
=0.95 \times 10^{9}\end{array}$} \\
\hline 2 & $1.9 \times 10^{7}$ & 97 & $2 / 6$ & $4 / 8$ & 50 & & \\
\hline 3 & $3.5 \times 10^{6}$ & 88 & $1 / 6$ & $2 / 11$ & 18.1 & & \\
\hline 4 & $2.6 \times 10^{5}$ & 73 & $1 / 6$ & $1 / 15$ & 6 & & \\
\hline 5 & $4.0 \times 10^{4}$ & 66 & $0 / 6$ & $0 / 20$ & 0 & & \\
\hline
\end{tabular}

"Reading taken in a Klett-Summerson colorimeter at $640 \mathrm{~nm}$.

Mortality ratio calculated according to the formula of Reed and Muench, 1938.

Table 3. Effect of BF-1 on survival of challenged mice

\begin{tabular}{cccccc}
\hline \multicolumn{3}{c}{ Control Group $^{*}$ [Without BF-1] } & \multicolumn{3}{c}{ Test Group $^{*}$ [with BF-1] } \\
\hline Saline/mouse & Mice died [Out of 40] & \% Mortality & Injected/ mouse Mice died [Out of 20] & $\%$ Servility \\
\hline $0.1 \mathrm{ml}$ & 32 & 80 & $30 \mathrm{mg}$ & 8 & 60 \\
& & & $60 \mathrm{mg}$ & 0 & 100 \\
\hline
\end{tabular}

${ }^{*}$ Received a challenge dose of $0.95 \times 10^{9} \mathrm{CFU}$ in $0.5 \mathrm{ml} \mathrm{BHI}$ of Salmonella typhimurium NCTC 74 ${ }^{* *} p<0.01$, using chi-square test.

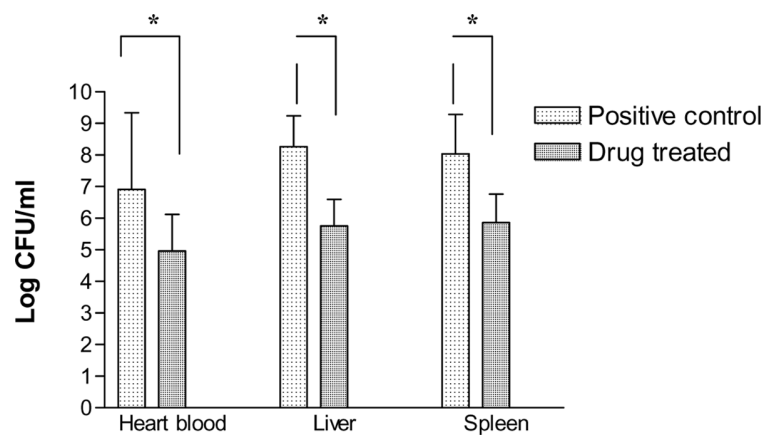

Fig. 4. Effects of BF-1 on CFU counts of Salmonella typhimurium NCTC 74 in organs of acute infected mice. *Viable counts between two groups significant; $p<0.01$.

$\mathrm{h}$ after challenge, compared with the control (saline treated) mice. Statistical analysis showed $p<0.01$ for $18 \mathrm{~h}$ samples.

The histopathological sections of liver revealed a considerable 10 fold decrease $(p<0.05)$ in number of severe infiltration with granular leucocytes and numerous micro-abscesses in infected mice treated with BF-1 as compared to the untreated ones.

\section{DISCUSSION}

The physico-chemical properties of the isolated flavonoid compound BF-1 were found to be identical with those of an authentic sample of a standard flavonone compound, quercetin (Sigma, USA) (Harborne, 1983). From previous reports, it is known that the $B$. frondosa flowers contain flavonoids. Along with the chalcone-free butein and butin, the other significant constituent is butrin. Isobutrin, which gets converted to butrin on storage, is also present. The plant gives a red gum, called Bengal gum or Butea gum.

Seeds yield a yellow oil, proteolytic and lipolytic enzymes palasonin, h-heneico-sanon and lactone, alpha-amyrin, b-sitosterol, b-D-glucoside, sugars and mono-spermin. Lectins are also found [www. tattvasherbs.com].

Naturally occurring products from plants have played a major role in the discovery of active therapeutic agents since ancient times. One of the foremost examples is quinine that was obtained from the Cinchona bark. B. frondosa has a strong anthelmintic effect. Extracts of different parts of the plant has been studied. It is used in Ayurveda as a rasayana and anthelmintic. Palasonin, an active principle in seeds, works effectively against Ascaris lumbricoides in vitro and in vivo on Toxocara canis, at 
levels similar to piperazine. In mice, the $\mathrm{LD}_{50}$ was $7.5 \mathrm{~g} / \mathrm{kg}$. Chronic oral exposure to substantial doses of the seeds of the plant leads to nephrotoxicity and anaemia in rats (Ramachandran $e t$ al., 2004), dogs and rabbits (Mengi and Deshpande, 1995; Kawase et al., 2000). Hepato- and splenomegaly, with congestion, gross dilatation of the stomach and gastric inflammation were also seen. The seed oil showed cardiac effects with inhibition of ventricular movement, reduction in the amplitude of contraction of isolated frog heart and duodenal muscle relaxation in the rabbit (Kawase et al., 2000). This study, along with earlier studies (Shirataki $e t$ al., 2001; Dastidar et al., 2001, 2004; Mazumder et al., 2003) has proved that various plants are still some of the rich sources of products with efficient medicinal values. Flavones are phenolic structures containing one carbonyl group. Flavonoids are also hydroxylated phenolic substances but occur as a $\mathrm{C}_{6}-\mathrm{C}_{3}$ unit linked to an aromatic ring (Fig. 1). Since they are known to be synthesized by plants in response to microbial infection (Dixon et al., 1983; Soman et al., 2004), it should not be surprising that they have been found in vitro to be effective antimicrobial substances against a wide array of microorganisms. Their activity is probably due to their ability to complex with extracellular and soluble proteins and also with bacterial cell walls. Their beneficial effects on the immune systems may be brought about by their ability to increase innate immune defense mechanisms (Gubarev et al., 1998). Quercetin, the flavonoid compound possessing two six-membered fused rings as chromanone (present in quercetin), has often been reported to possess antimicrobial activity. However, the presence of this compound in stem bark of Butea frondosa is yet unreported. Moreover, although several parts of this plant have been investigated and have yielded products of clinical importance, its stem bark has not been explored for antimicrobial properties. This study reports the existence of quercetin in the stem bark of Butea frondosa and presents its antimicrobial spectrum in vitro and in vivo. It further suggests that quercetin, isolated from stem bark of Butea frondosa, has potential for being developed into an antimicrobial agent that is expected to assist in the general battle against antibiotic-resistant bacteria.

\section{ACKNOWLEDGEMENTS}

This work was supported by grants provided by the Department of Science and technology, West Bengal, India.

\section{REFERENCES}

Anonymous. (1998) The Wealth of India, Vol-2. New Delhi, India: Publication and Information Directorate, CSIR, 341-347.

Barrow GI, Feltham RKA. (1993) Cowan and Steel's Manual for the identification of medical bacteria, Cambridge University Press, Cambridge, UK.

Bhatwadekar AD, Chintawar SD, Logade NA, Somani RS, Kasture VS, Kasture SB. (1999) Antistress activity of Butea monosperma flowers. Indian J. Pharmacol. 31, 153-155.

Breitmaier E. (1993) Structure Elucidation by NMR in Organic Chemistry, A Practical Guide, 1st edition. West Sussex: John Wiley \& Sons, 1-69.

Cohen ML. (1992) Epidemiology of drug resistance: Implications for a post antimicrobial era. Science 257, 1050-1055.

Dastidar SG, Mahapatra SK, Ganguly K, Chakrabarty AN. (2001) Antimicrobial activity of prenylflavanones. In vivo 15, 519-524.

Dastidar SG, Manna A, Kumar AK, Mazumdar K, Dutta NK, Chakrabarty AN, Motohashi N, Shirataki Y. (2004) Studies on the antibacterial potentiality of isoflavones. Int. J. Antimicrob. Agents 23, 99-102.

Davies J. (1994) Inactivation of antibiotics and dissemination of resistance genes. Science 264, 375382.

Davies J. (1996) Bacteria on the rampage. Nature 383, 219-220.

Dixon RA, Dey PM, Lamb CJ. (1983) Phytoalexins: enzymology and molecular biology. Adv. Enzymol. 55, 1-69. 
Gubarev MI, Enioutina EY, Taylor JL, Visic DM. Raymond A. (1998) Plant derived glycoalkaloids protect mice against lethal infection with Salmonella typhimurium. Phytother. Res. 12, 79-88.

Harborne JB. (1983) Phytochemical methods (A Guide to Modern Techniques of Plant Analysis), 1st 341 edition. London: Chapman and Hall.

Kapila K, Bhide NK, Razdan MK. (1970) The antifertility effect of Butea frondosa petals (alcoholic extract and its crystalline fraction). J. Indian Med. Assoc. 55, 60-61.

Kawase M, Motohashi N, Debnath S, Mahapatra S, Dastidar SG, Chakrabarty AN. (2000) Antimicrobial activity of new coumarin derivatives. Arzneim.forsch. Drug Res. 51, 67-71.

Kirtikar KR, Basu BD. (1975) Indian Medical Plants, Vol-1, 2nd edition. Allahabad, India: Lalit Mohan Basu, 758.

Koneman EW, Allen SD, Janda WM, Schreckenberger PC, Winn WC Jr. (1997) Colour Atlas and Textbook of Diagnostic Microbiology, 5th ed, Lippincott, USA.

Krogstad DJ, Moellering RC. (1990) Combinations of Antibiotics, Mechanisms of Interaction against Bacteria, Chapter 11. In: Antibiotics in Laboratory Medicine, Lorian V, Williams and Wilkins, Baltimore/London, 298-331.

Lal J, Chandra S, Raviprakash V, Sabir M. (1976) In vitro anthelmintic action of some indigenous medicinal plants on Ascardia galli worms. Indian J. Physiol. Pharmacol. 20, 64-68.

Markham KR. (1982) Techniques of Flavonoid Identification, 1st edition. London: Academic Press INC., 36-51, 72-93.

Mazumder R, Dastidar SG, Basu SP, Mazumder A, Kumar. (2003) Emergence of Mesua ferrea Linn. leaf extract as a potent bactericide. Anc. Sci. Life 22, 160165.

Mazumdar K, Dutta NK, Dastidar SG, Motohashi N, Shirataki Y. (2004) Phytochemical isoflavones against diabetic foot bacteria. Orient. Pharm. Exp. Med. 4, 261-266.

Mengi SA, Deshpande SG. (1995) Comparative evaluation of Butea frondosa and flurbiprofen for ocular anti-inflammatory activity in rabbits. J. Pharm. Pharmacol. 47, 997-1001.

Nadkarni KM, (1976) Indian Materia Medica.
Mumbai, India: Bombay Popular Prakashan, 222.

National Committee for Clinical Laboratory Standards. (1993) Methods for Dilution in Antimicrobial Susceptibility Tests; Approved Standard M2-A5. NCCLS, Villanova, PA.

Neu HC. (1992) The crisis in antibiotic resistance. Science 257, 1064-1073.

Nikaido H. (1994) Prevention of drug access to bacterial targets: permeability barriers and active efflux. Science 264, 382-388.

Plummer DJ. (1985) An Introduction of Practical Biochemistry. New Delhi, India: Tata McGraw-Hill Publishing Co. Ltd.

Ramachandran S, Sridhar Y, Sam SK, Saravanan M, Leonard JT, Anbalagan N, Sridhar SK. (2004) Aphrodisiac activity of Butea frondosa Koen. ex Roxb. Extract in male rats. Phytomedicine 11, 165168.

Rane A, Grampurohit N. (1998) Hepatoprotective activity of Pterocarpus marsupium Roxb. and Butea frondosa Koenigex. Roxb. Indian J. Pharm. Sci. 60, 182-184.

Razdan MK, Kapila K, Bhide N. (1970) Study of the antioestrogenic activity of alcoholic extract of petals and seed of Butea frondosa. Indian J. Physiol. Pharmacol. 14, 57-60.

Reed LJ, Muench H. (1938) A simple method of estimating fifty percent end points. Amer. J. Hyg. 27, 493-497.

Shah KG, Baxi AJ, Shukla VJ, Dave KK, Ravishanker B. (1990). Phytochemical studies and antiestrogenic activity of Butea frondosa flowers. Indian J. Pharm. Sci. 52, 272-275.

Shirataki Y, Motohashi N, Tani S, Sakagami H, Satoh K, Nakashima H, Mahapatra SK, Ganguly K, Dastidar SG, Chakrabarty AN. (2001) In vitro biological activity of prenylflavanones. Anticancer Res. 21, 275-280.

Soman I, Mengi SA, Kasture SB. (2004). Effect of leaves of Butea frondosa on stress, anxiety, and cognition in rats. Pharmacol. Biochem. Behav. 79, 1116.

Spratt B. (1994) Resistance to antibiotics mediated by target alterations. Science 264, 388-393.

Tandon R, Shivanna KR. (2003). Reproductive Biology of Butea monosperma (Fabaceae). Annal. Botany 92, 715-723. 
Travis J. (1994) Reviving the antibiotic miracle? Science 264, 360-362.

Trease GE, Evans WC. (1985) Pharmacognosy, 12th edition. English Language Book Society, Bailliere, Tindall.

Wallis TE. (1985) Text Book of Pharmacognosy. Shahdara, Delhi: CBS Publisher and Distributor,
252.

Washington JAH, Sutter VL. (1980) Dilution susceptibility test: agar and macro-broth dilution procedures. In: Lennette EH, Balows A, Hausler WJ Jr, Truant JP, eds. Manual of clinical microbiology, 3rd edition. Washington, D.C.: American Society for Microbiology, p. 453-458. 